Chris Bolsmann and Henry Miller

School of Languages and Social Sciences

Aston University

Birmingham

c.h.bolsmann@aston.ac.uk

Chris Bolsmann has taught in sociology in departments at the University of Pretoria and the Rand Afrikaans University in South Africa and at Aston University since 2004. He has published on trade union internationalism and the transformation of higher education in South Africa.

Henry Miller has taught at the Borough Polytechnic (South Bank University), Moray House College of Education in Edinburgh and since 1971 at Aston University in the Education Department, Business School and the School of Languages and Social Sciences. He has published widely on teacher professionalism, secondary education and the management of universities in Australia, Canada and the UK. 


\title{
International student recruitment to universities in England: Discourse, rationales and globalisation
}

\begin{abstract}
The recruitment of international students to universities in England has become a central issue in an era of globalisation for university administrators, senior managers, international offices and heads of schools and faculties. We examine the policy rationales for the recruitment of international students to England. Through the use of in-depth interviews with key role players at four English universities, we compare the rhetoric, rationales and reasons for the recruitment of international students. A range of discourses can be identified in the recruitment of international students and an economic competition rationale is dominant. This is expressed within the discourse of globalisation.
\end{abstract}

Keywords

Recruitment, international students, rationales, globalisation 


\section{Introduction}

We examine the policy rationales and discourses used in the recruitment of international students to universities in England in an era of globalisation. We outline the development of policy and practice towards the recruitment in the United Kingdom (UK) from the 1960s to 2005, and the recent patterns in the context of recruitment to Anglophone countries. We discuss the location of discourses of globalisation and internationalisation to higher education. Three discourses are specifically relevant towards the recruitment of international students: academic internationalism, economic competition and developmental. We describe our methodology and report responses of our informants who included senior managers and international officers in four different English universities. In our conclusion we identify the dominant discourses and their different articulations to the universities. Our interview data illustrates the different interrelated discourses which operate at the level of the university. They reflect the broader rationales for the recruitment of international students at the level of the state within the international context. The dominant rationale is primarily economic competition and this is expressed within the discourse of globalisation.

\section{International students, fees and numbers in the United Kingdom}

Prior to 1967 international students in the UK paid the same fees as home students and were effectively subsidized out of public funds (Williams, 1987: 107). International students in the UK grew from 28,000 in $1955-6$ to 64,000 in $1962-3$ and in this period 
they were seen as contributors to international relations and development, as an enrichment of student life, a source of students for vacant places, and 'lastly' a source of revenue (Silver and Silver, 1997). However, after 1967 international students paid higher fees than home students. In 1977 a student quota limit was introduced for international students to reduce public contributions to higher education in the UK, and in particular, the subsidization of foreign students (ibid). By 1978 the numbers of international students in the UK had peaked at 90,000 and 'education remained heavily subsidized' (Williams, 1987: 107). In 1979, the Conservative Government raised the cost of fees for all nonEuropean Union (EU) international students (with certain exceptions such as students from the Commonwealth), and lifted the quota scheme. The decision to increase student fees 'sent shock waves through a number of Britain's international relationships' and 'severely affected the flow of students... and promoted re-evaluation of policy towards overseas students' (Overseas Students Trust, 1987: 1). Thus while international students were initially subsidized and seen as a cost to the system, from the 1980 s they came to be viewed as a benefit in economic terms to universities, the state and the economy. The shift that viewed international students primarily as a source of revenue dates from 1979 with the accession of the Thatcher Government. This was part of a broader shift in policy and discourse towards neo-liberalism where universities are seen as contributors to the national economy and are expected to compete globally for international students who would pay fees. Blair adopted much of the neo-liberal orientation and emphasized globalisation as the context within which universities could contribute to the competitive knowledge economy. 
Universities UK is a body made up of the Vice-Chancellors or Principals of UK universities. In its 2005 international strategy, Universities UK stated

'UK universities and the UK as a whole benefit greatly from international activities and, particularly, from the opportunity to educate citizens of other countries. This provides the UK with significant geopolitical and cultural benefits as well as broadening the educational experience of UK students and ensuring the diversity of the student body. The international activities of UK universities make an important and growing contribution to their income and export earnings for the UK economy.' (quoted in Leadership Foundation for Higher Education, 2006: 4).

The above quotation highlights the perceived importance of international students and their contributions to the UK in a variety of spheres.

One difficulty in developing an analysis lies in the definition of what constitutes an international student. There is a process of identity construction for international students dependent on the local context (Devos, 2003). In the UK a distinction is often made between international students, often designated 'overseas students' and EU students, including British students, on the basis of the differences in fee regimes. EU students pay the same fees as UK domiciled students in British universities. International students (this includes those who originate from European states who are not members of the EU) pay different (higher) fees. In this (narrower) definition used by university administrations, there is emphasis on the financial and economic aspect of the recruitment of students. For 
the purposes of our overall analysis, we use the broader definition when we refer to international students, as to all non-UK domiciled students.

In the 21 st century international students, in terms of the broad definition to include all foreign students, constitute a significant part of the student populations, particularly at postgraduate level in many advanced developed economies such as Anglophone Australia, Canada, the UK and the United States (US). The US has the most international students with 491,000 in 1999 and 586,000 in 2003 (British Council, 2004: 29). In 1999, this 'export' generated more than US\$9 billion (fifth place amongst US service export industries). Measured by revenue and numbers, the UK, Australia and Canada follow (Scherrer, 2005: 486). However, if we looked at student numbers not revenue, after the UK follow countries in which study in higher education has been low cost or free and open to all: France and Germany (Larsen et al, 2001: 8-14) figure prominently.

British education and training is ranked amongst the top five sectors that generate export income ahead of insurance and behind transport (Tysome, 2004b). There are approximately 2 million students globally who study outside their countries of origin (Altbach, 2004b: 18). This figure is up from 1 million in 1980 (Marginson, 2002: 413). Within the English speaking market for international students, the UK attracts almost $25 \%$ of students in second place behind the US. Within the international market overall, the UK attracts around $12 \%$ of students (MacLeod, 2004). England attracts over $84 \%$ of international students who study in the UK. In 2004-5 there were over 318,000 international students (EU and non-EU) enrolled in higher education institutions in the 
UK (MacLeod, 2006a). This figure represents over 10\% of students in higher education in the UK. The numbers are up from 198,000 in 1997, 213,000 in 1999 and 273,000 in 2003 (British Council, 2004: 29). Approximately 175,000 of these students originated from outside the EU (Tysome, 2004a). Nearly two thirds of all international students in the UK originated from China, Hong Kong, Malaysia, India and Singapore in 2003. In 2003 international students contributed $£ 3$ billion to the British economy with $£ 1,5$ billion generated from fees (ibid). Furthermore, revenue from the export of goods associated with education and training includes: educational publications and equipment and consultancy services that generate over $£ 13$ billion (ibid). Within the Commonwealth, the UK charges the highest fees for education and up to 50\% more than institutions in Australia and New Zealand (Jobbins, 2004).

\section{Globalisation and the recruitment of international students}

Many authors have written on the impacts of globalisation on universities (see for example Currie and Newson, 1998; Walker and Nixon, 2004; and Scott, 1998). However, Altbach (2004: 4a) reminds us that in the Middle Ages 'universities represented global institutions' that used a common language (Latin), and comprised of international teachers and students. In Europe as institutions, the Roman Catholic Church, the British Parliament and around 70 universities were established by 1520 and are still present today (Kerr, 2001: 15). For Altbach (2004a) universities have always operated within a global context. 
These figures illustrate how international students and higher education operate within the global context. They also indicate why we have chosen England (within the UK) as focus of our analysis. The functioning of universities within the contemporary global context can be defined as internationalisation in which 'specific policies and programmes undertaken by governments, academic systems and institutions, even individual departments or institutions to cope with or exploit globalisation' (Altbach, 2004a: 6). Internationalisation like globalisation is a contentious and problematic concept to define. Yang, (2002: 92) draws a distinction between globalisation and internationalisation in terms of origin, impetus and priorities manifested in 'economic' versus 'human interests'. Knight (2003a: 2) proposes a definition: 'internationalization at the national, sector, and institutional levels is defined as the process of integrating an international, intercultural, or global dimension into the purpose, functions or delivery of postsecondary education'. The recruitment of international students can be seen as internationalisation that engages with the processes of globalisation that are primarily economic and competitive but also as worthwhile and valuable in its own right.

An aspect of globalisation is the regulatory frameworks that are developed on a global scale. These can range from bilateral agreements between individual nation-states, through to regional cooperation as represented in the Bologna process and to discussions on the General Agreement on Trade in Services (GATS). Robertson et al (2002) write on the World Trade Organization (WTO), GATS and education and Rizvi and Lingard, (2006) on the Organization for Economic Development and Cooperation (OECD) and education; they critique the power of the neo-liberal agenda and the way it shapes policy 
and practice in education generally. This particularly applies to its influence on universities and their provision for international students. The WTO and OECD have considerable clout that influences and promulgates a neo-liberal agenda within a globalisation discourse of market driven economic competition.

The OECD, in a policy brief the Internationalization of Higher Education (2004) (quoted in Rizvi and Lingard. 2006: 258) put forward four rationales for international higher education. These are: 'a mutual understanding; skilled migration; revenue generation; and capacity building'. It argued that these rationales are not mutually exclusive and have a strong economic drive, seem to privilege the economic interests of the developed countries as 'the Organization seems to regard it as perfectly understandable that the aim by the developed countries to recruit talented students from the developing countries "to work in the host country's knowledge economy, to render its higher education or research sectors more competitive"” (quoted in Rizvi and Lingard, 2006: 258-259). This shows little regard to the loss to the countries from which the students are recruited.

The neo-liberal market agenda has been dominant in the US, UK and Australia for the last twenty five years. It finds expression not only amongst economists and policy think tanks but also in the pronouncements of heads of states and ministers of education. It sees education, including higher education as both an investment in human capital which will enhance competitiveness and rewards to the individual, corporations and the national economy. This view stresses the economic importance of education, and sees market competition as the most efficient means for the delivery of goods and services. This 
constructs academics, departments, and universities as competitive providers of a service and students as rational, individual consumers who can know what they are buying. There can be a tendency for knowledge and learning particularly when provided in discrete modules to be viewed as a commodity, to be provided and bought (Naidoo and Jamieson, 2006). This neo-liberal agenda market agenda is located within the broader process and ideology of globalisation.

\section{Globalisation, discourse and internationalism}

Goldberg (2006) provides a useful conceptualisation of the manner in which different discourses, some predominant some subaltern, relate to each other in specific national and institutional contexts. She draws on Ball's (1998) notion of policy as discourse and develops the concept of a discursive policy web which can show the way in which 'multiple discourses interact [to form] a complex network of power (Goldberg, 2006: 78). Her analysis explores the way in which the hegemonic discourses of globalisation and neo-liberalism are politically negotiated and mediated.

When we consider the way in which multiple discourses form and constitute policy and practice of university academic mangers, we are on similar terrain to Goldberg's (2006) analysis in Canada or Devos's (2003) analysis in Australia. We too recognize the power of the overarching discourses which claim truth for globalisation and neo-liberalism. These discourses are articulated by politicians, policy makers and commentators at the national and international level. They replace previous dominant discourses, Keynesian 
economic management and social democratic education and equity policies or nation building (Marginson, 2002). This is particularly apposite when we consider how universities' international offices formulate policy to recruit international students in terms of an economic language of the market.

At the level of the UK state represented by policy statements by Tony Blair, we see a variety of rationales - competing, complimentary, and contradictory; often conflated, bland statements which use a discourse of globalisation to disguise the conflicts in rationales between economic and educational aims. This can be seen in the final paragraph of Blair's article in The Guardian of April 182006 entitled 'Why we are putting up millions to attract students from overseas'. This starts with 'the UK is a world leader in the recruitment of international students' - an assertion of the desirability of this process - but which finishes with a conflation of different rationales: 'I have always said that embracing globalisation as one of the great challenges of the $21^{\text {st }}$ century will benefit the UK massively, and education is absolutely fundamental to that. Encouraging more talented students from overseas to come here will make the UK stronger, brighter and better place to learn, for all our students' (Blair, 2006: 2). It is not clear what 'embracing' means but it is reasonable to suppose that it includes a stance on the part of the university managers that sees international students primarily in terms of an economic rationale which emphasises not just the fees they bring in but also the contribution they make through research to the UK's economy and corporate competitiveness.

There are a number of traditions represented in different discourses and policy rationales 
towards internationalisation. As in the case of defining internationalisation, identifying rationales is problematic due to different university contexts (Yang, 2002). Knight and De Wit $(1995,1997,1999)$ list four broad categories that are the social/cultural, political, academic and economic. The socio/cultural dimension includes issues of "national cultural identity; intercultural understanding; citizenship development; and social and community development' (Knight, 2003b: 9). At the level of the political this is manifested as 'foreign policy; national security; technical assistance; peace and mutual understanding and national and regional identity’ (ibid). In terms of the economic category this is made up of 'economic growth and competitiveness; labour markets and financial incentives' (ibid). Finally the academic category refers to the 'international' dimension of research and teaching; extension to academic horizon; institution building; profile and status; enhancement of quality; and international academic standards' (Knight, 2003b: 10). The four categories are useful as they identify the rationales for internationalisation. However, Knight (2003b) concedes that these need to be further developed and uses the categories in a discussion at the levels of the national and institutional. At the level of the national we can identify the following rationales: 'human resource development; strategic alliance; commercial trade; nation building and social cultural development' (Knight, 2003b; 10-11). The institutional rationales are represented as 'international branding and profile; income generation; student and staff development; strategic alliances and knowledge production' (Knight, 2003b: 12-14).

Koutsantoni, (2006: 15) draws on and develops from Knight (2003b), and categorises governmental internationalisation strategies into 'internationalisation driven by broadly 
academic/cultural rationales'; 'internationalisation driven by economic rationales'; and 'internationalisation driven by emerging rationales (related to economic)'. The final category primarily refers to developing states where issues of human resource development and the brain drain are important. Universities can provide the opportunity for cultural and social development (Barnett, 1990). Yang (2002: 85) argues that 'the rationale for internationalisation lies in an understanding of the universal nature of the advancement of knowledge'. Universities are by nature international in their outlook and should cooperate in their search for knowledge. Scott (2000) suggests how the internationalisation of universities was manifested in terms of imperial expansion and the universal nature of science. Scott (2000: 5) remarks that 'in a rhetorical sense, of course, internationalism has always been part of the life-world of the University'. Yet, half of all universities globally were established after 1945 and three-quarters after 1900 (Scott, 2000: 5). Thus Scott (2000) argues modern universities are national institutions and were created to address national issues. In an era of globalisation this model is under threat (Marginson, 2002). The older co-operative models of internationalism and the national university are increasingly challenged by the need to become economically viable institutions that generate income, compete on a global market and contribute to economic competition.

\subsection{University rationales for the recruitment of international students in England}

Our research and analysis is primarily concerned with the rationales of international student recruitment that represents a part of the internationalisation strategies of 
universities and nation states. The discussion of the rationales for internationalisation provides basis for our identification of three major strands or traditions present in the recruitment of international students. The first is a 'Republic of Letters or of Science' tradition of universities that recruit international students. This we can label 'Academic Internationalism'. This strand represents the oldest idea(1) of the international 'Republic of Letters or of Science', where universities are places of learning, research and scholarship which attract students, scholars and teachers irrespective of their national origin (Altbach, 2004a; Yang, 2002). Fenwick (1987: 128) refers to an 'international exchange' that 'implies reciprocity of benefit, an overall net gain to the individuals concerned and the quality of future international understanding'.

The second is an economic discourse which uses the language of costs and benefits, a 'Economic Competition' discourse. 'Academic Internationalism' becomes 'Economic Competition' and at the level of the university the recruitment of international students is seen as an economic resource for the institution. There is increased competition between institutions and nation-states in economic terms to provide the education and training which returns income. This is not only in terms of the attraction of international students to the home country, but also in the provision of distance education or the establishment of programmes and indeed whole institutions, colleges or universities abroad. These projects are economic ventures to generate income, enhance brand awareness and provide a feeder institution which will facilitate students continuing their education in the metropolitan university. 
The economic contribution of international students goes beyond the immediate fee income. In some areas of postgraduate work the employment of postgraduate students as researchers, the marginal costs may be higher than the immediate fee that the students bring in, but they nevertheless make a net economic contribution through their participation in research which itself generates income. Excellent international researchers make significant contributions to university research programmes - both blue sky and applied research programmes. These feed and develop the economic capacity and competitiveness of both corporate and national economies. This, then, is the link between the economic rationale at the level of the university and policy and practice at the level of the state and corporation (Guo, 2005; Miller, 2006).

The third strand involves a civilizing, controlling, training and development discourse originating in colonial empires and this we classify as 'Developmental'. Traditionally this was manifested in the provision of education and training for colonies abroad. This had elements of a religious missionary or more general civilizing mission. Historically in the case of the UK it was focused on the colonies and dominions. After 1945 with decolonisation, this provision became increasingly conceptualised as developmental help for the underdeveloped countries. It included the establishment of colleges and universities under the auspices of British universities, such as Makerere in Uganda which affiliated to the University College of London in 1949. As far as international students are concerned, there have been a variety of courses provided in the UK, some of them directly vocational for the ex-colonies' administrators but more generally in law, medicine, the military and more recently business. Fenwick (1987: 128) refers to this 
type of relationship as 'the modernization model of Third World development'.

In the UK, the British Council maintains linkages with former colonies and territories (Room, 2000). The global cultural hegemony of the US functions in a similar manner in attracting international students. Room (2000: 111) argues that a form of 'academic entrepreneurialism' has emerged where 'the market for overseas students is politically constructed and maintained'. This is 'underpinned by traditional linguistic and cultural links' (ibid). We have a continuation of former imperial and political connections that have evolved into financially beneficial markets and sources of income for Western universities, particularly in the US and the UK. This is a manifestation of the ideology of globalisation that extends from the political and cultural to the economic domain.

\section{Research settings and methodology}

In our research we conducted 16 interviews at four English universities. The universities can be characterized as: Big Civic or Redbrick such as Bristol, Manchester and Sheffield; new universities established in the 1960s on suburban campuses, sometimes known as the Shakespearian Seven; White Tile or County including Essex, Sussex and York. The excolleges of advanced technology (ex-CAT) such as Bradford, Brunel and Salford. The expolytechnics receiving university status (post-1992) like De Montfort, South Bank and Sunderland. There are other categories e.g. Oxbridge, London University Colleges, smaller Civic universities, Scottish, Welsh and Northern Irish institutions and the Open University all with distinctive features which influence their policies towards the 
recruitment of international students. We have focused on a representative institution from the Big Civic, Shakespearian Seven which we have described as a County university, a post-1992 university and an ex-CAT. Together these constitute a representation of the mainstream of English universities. We acknowledge that Oxbridge and London University Colleges play a significant and elite role in the dynamics of international student recruitment (see Marginson, 2006).

The percentage of international students at these four universities in 2004-5 was as follows: Big Civic 15\%; County university 23\%; ex-CAT 14\% and post-1992 university 7\%. We selected key informants from the different universities and interviewed them to generate our research data. We initially approached the international offices of each of the universities and interviewed the director or senior personnel. Thereafter, we interviewed senior academic managers in the respective universities and these included Academic Registrars, Vice-Principals, Pro-Vice Chancellors and Heads of Schools and Faculties. The interviews were semi-structured in nature that allowed for the respondent to elaborate and discuss certain aspects at will. In all cases, except one, the interviews were recorded for transcription purposes and these ranged in duration from 25 through to 75 minutes. Respondents were informed that they would not be quoted by name. A draft of the paper was sent to all interviewees and in a few cases respondents made further comments and suggestions.

\section{Academic Internationalism: Status, community and diversification}


The responses we quote illustrate the variety of complementary and contradictory discourses within which policy and practice works. They include the notion that the presence of international students is an indicator of the high international status of the university. This is sometimes articulated within the more general notion of international students who contribute to the academic community and of the value of diversity and cultural exchange for its own sake. Sometimes the diversity is seen in instrumental terms as of direct benefit in the delivery of courses e.g. international marketing on an MBA. International students are certainly seen as a source of fee income but they are also seen as contributors to the status of the university as an international institution, as an essential part of the academic community and a crucial part of the research effort. When these senior academic managers and international officers were asked why they recruit international students, more often than not they first identified a reason and rationale other than revenue. From the Big Civic university

'part of this university's history... a long tradition of recruiting international students...a core value, we see ourselves as part of an international community...that they produce a significant income stream is true, but [this] is not the main driver. The academic rationale is being part of an international community involving transfer of knowledge and debate that takes place across many countries.'

A representative from the County university suggested 
'international students improve the university's performance...it is much more than a financial issue. The graduate population contribute to research output and the undergraduates define what a university is. Research groups in sciences would not be able to function without PhDs and post doctoral [students] who are drawn internationally, as are our staff.'

In certain areas, notably in business schools with MBAs and masters programmes, the presence of significant numbers of international students can be taken as an indication of quality. A representative from the ex-CAT commented that 'on the MBA international students and the international experience is taken as a measure of quality'.

As well as the cash benefit, a significant driver for the recruitment of international students is identified as: 'to make an international university'. This was a strong theme amongst academic managers in three of the four universities we researched.

However, across all four universities there was concern to avoid the creation of national 'education ghettos' and there was often an emphasis on running programmes which, while they attracted substantial numbers of international students with the advantage of diversity, also included a significant percentage of UK students. In one case, this may even lead to a differential fee structure, where fees for UK students could be discounted by as much as $50 \%$ in order to attract a target of $20 \%$ UK students on a postgraduate programme. The respective international offices referred to the need to maintain a diverse student population. This point is made by Habu (2000: 44) in her research on experiences 
of Japanese students in the UK where a 'motivation to globalise higher education is to encompass diversity'. In addition, Habu (2000) suggests that a community made up of scholars from across the world is seen as selling point in the recruitment of new students. The representative from the international office of a Big Civic recruited international students because the 'key reason is part of our strategic plan to be a leading world university and a leading research led university and by the very nature of that [we] have to be international, to attract the best staff, students and participate in collaborative research as well'.

At the cultural level for the university, the international focus of the institution gave their students 'a global perspective to prepare them as global citizens'. This rationale for attracting international students is similar to that of the County university where 'they bring with them different experiences and perspectives and really enrich seminar discussions and research'. The aim of becoming a leading global player is repeated when the 'ambition [is] to become a world class university and in order to do that and break out from being a good UK university, to becoming an internationally acclaimed university, then you have to have international students and to be known overseas'.

The recruitment of international students in an attempt to become a world class university is closely linked to 'the international status' of the institution. This in turn, is reflected in the staff of the institution who 'need to have an international focus and their research should be of international importance'. Home students as well are expected to be 'international in their focus, in their culture and prepared for the workplace'. The 
financial spin off of the importance of status is not lost on the international representative of the ex-CAT where 'reputation and recognition for international students in the market place' allows the university 'the luxury of charging more' and 'if you have got the reputation or the perceived reputation you can charge and pull those people in'.

The recruitment of international students brings diversity to campuses as well as lecture halls, but a balance is sought so that one nationality is not 'over represented' on campus. The international representative of the County university maintained that 'our office has always tried to ensure diversity on the campus and we have always been very careful to try and ensure that the university as a whole is not dominated by a particular national group and that you have got a good cross spread of students'. A senior manager in the business school of the County university stressed that 'we don't want a separate cultural group, we want an integrated group to bring something to the table'. For the representative of the international office at the ex-CAT this is stressed where 'ethnically we have got to balance it out and that is why we have to diversify'.

At the same time as our respondents register the importance of the contributions made by international students, the representative of the ex-CAT remarks that 'we also didn't want to be a university full of Chinese students...they are not going to want to be in a class full of Chinese students...they want to come to Britain to have an international education and as an institution that is our duty to try and ensure that they get an international exposure'. This point is also made by a senior academic manager in the business school of the County university who says 'because of globalisation we have a diverse student 
population and try and keep some diversity amongst the overseas students rather than all Chinese, or at one time [we were] all Hong King Chinese or Malaysian and these markets tend to go in booms and busts'. Universities need to ensure their lecture halls have a 'good mix' of students of different nationalities, but also there is danger of relying on income from one market. The respondent illustrates this theme well: 'so we work hard to stimulate applicants from all over the place and not just going for the easy pickings...so now we are interested in diversity as well, but also from an economic point of view'.

\section{Global Competition: Fees and university and national economies}

International students make up a significant percentage of the student body of British universities, but they are even more important as a large proportion of the income stream that contributes to the overall budget. The size of this contribution is uneven both within and between universities. Proportions of fees generated from non-EU students for institutions vary across the sector. During 2003-4 the largest were: London School of Economics and Political Science (LSE) 33.5\%; School of Oriental and African Studies (SOAS) 31.9\%; London Business School 19.3\%; Essex $17.8 \%$ and Luton $17.7 \%$

(MacLeod, 2006b: 2). The proportion of international students on postgraduate courses, MScs, MBAs and PhDs particularly in engineering and business schools can be very high, while proportions in undergraduate degrees or arts faculties are often low. At the university level most of our respondents recognise the importance of the financial contribution even if this is qualified by reference to other contributions in terms of diversity or international status. 
An academic manager at the post-1992 university suggests 'the main driver to be honest is financial, the second is diversity in the student population and this drives changes in curriculum and courses...programmes include globalisation'. A senior academic manager at our County university argues 'of course there is the financial contribution, that is an obvious one. International students are a major fee earner'. In addition, a senior academic within the business school at the County university argues that 'initially it was to replace lost income from the government... it was done for economic reasons now it is done as the global reach to have international students'. At the Big Civic, a senior academic manager said 'the key reason is part of our strategic plan to be a leading university... and of course you can't deny that they bring with them full fee funding, so that helps the university as well'.

The relative importance of international students in financial and economic terms varies according to the balance between undergraduate and postgraduate, between revenue from teaching and research and also with the range of subjects available. Thus in a relatively small ex-CAT with half the schools recruiting large numbers of international students, income from student fees was more than $£ 9$ million and exceeded home/EU student fee income at around $£ 8$ million. However, this was balanced by substantial research revenue (non-fee) of nearly $£ 7$ million which was an important part of the overall budget.

In a large university with a wide range of schools and departments with only some of them recruiting international students and with substantial research revenue, fees from 
international students may contribute less than $10 \%$ of the total revenue. When assessing the financial contribution to universities, costs as well as revenue need to be taken into account. In all the universities where we conducted interviews that although the overall balance was recognised as being important, it was only recently that detailed calculations were being made in terms of cost and benefits. Up until 2004, the main concentration had been on revenue. Interest in careful costing has probably been prompted by not only advice from funding bodies about transparency, but also from the change in trend or blip in recruitment of international students particularly from Asia in the academic year 20056.

One of the features of the financial contributions of international students is that student numbers and fees charged are practically unregulated by UK funding bodies. As one academic manager put it 'we can charge what fees we like and take what number we like'. It is important to distinguish between different types of courses, particularly between undergraduate and postgraduate, but also within the postgraduate area, between certificates, diplomas, MScs, MAs, MBAs and PhDs. Usually in postgraduate courses costs are covered and often there are a significant, - note the language - 'surplus', 'profits' or 'earnings'. International students on research degrees may pay substantial fees, but they sometimes receive scholarships and bursaries and so they may not cover their costs to the university directly. Nevertheless, they may contribute to the economic as well as the academic viability of the university in the medium term. Often they are employed as research assistants on research projects and as lecturers or tutors for undergraduate programmes. While they contribute in general terms to the research culture 
of the university, more specifically they are writing papers - often as joint authors with supervisors or other members of academic staff who are submitted for the Research Assessment Exercise (RAE). They can therefore contribute financially in the medium term through high RAE scores. More generally, if extra staff can be employed through fees and revenue raised from international students at both undergraduate and postgraduate levels, these staff can earn research monies on the financial basis of being employed to teach international students.

At the undergraduate level, there is usually a substantial difference in fees. Prior to 2006, home and EU students paid $£ 1,150$ per annum while international students could pay up to $£ 8,000$. However, from 2006 with fees at $£ 3,000$ with $£ 2,250$ from the Higher Education Funding Council for England (HEFCE) for home students, the differences between home and international student revenue is less marked at the undergraduate level. This is one reason why in all four universities the main effort for the recruitment of international non-EU students was focussed at the postgraduate level.

At the undergraduate level at the post-1992 university, two of the academic managers in the business and engineering schools placed emphasis on strategic alliances. Strong links have been established mainly in China with a higher education institution, where students undertake their first two years and then transfer to complete the undergraduate degree in the UK. The advantage is that once established there should be a steady stream of students with appropriate training to spend two years in the host university with the possibility of a substantial percentage who proceed to a one year MSc course. The 
disadvantage is that setting up the alliance and monitoring and developing curriculum and pedagogy in conjunction with foreign universities takes considerable time and resources: it is often more than three years before any international students arrive in the UK. The advantage of developing one year masters or MBA courses is that students are recruited on the open market with appropriate qualifications and experiments can be undertaken without the commitment of resources for long periods of time.

One other significant feature of the recruitment of international students in our four universities was the wide range of fees charged for similar courses, ranging from $£ 10,000$ through $£ 19,000$ to $£ 25,000$ for an MBA at different institutions. In one instance it was stated that fees were 'fixed on an incremental basis in terms of the percentage over inflation'. At the same institution there was a discussion about the relationship between quality, price, prestige and branding. There was recognition that a well known 'brand', whether university, school or programme, could command a high price that was often seen as an indication of quality; and that if considerable revenue was being generated, facilities could be improved and expensive professors hired.

The 1997 Asian economic crash clearly resonated in higher education in the UK. The international representative from the ex-CAT said 'you cannot put all your eggs in one basket, the bubble could burst and that would be your income stream gone... we have started to pull away from China in the sense that we don't divert all of our resources into it'. This is also reflected in the recruitment patterns of the university: while Asia remains the biggest market, recruitment takes place in over 20 countries around the world 'so we 
are spreading our risk'. Nevertheless, China remains the single largest market for all the universities under discussion. This point is reiterated by the international representative of the County university: 'we are trying to reduce risk, because if something should happen to the Chinese market we do not want to be left with no students'. The tension and dominant rationale that faces international offices is captured by the representative from the ex-CAT

'if you talk to people in the finance department they see it as the bottom line...income is a huge factor...if universities did not charge would we encourage international students to the same extent? I suspect as a university we would not put it so high on the agenda.'

\section{Developmental: Neo-colonialism, education and training}

One of the traditions we identified in the provision for international students was to do with the training and education of nationals in developing countries. In the case of some European countries such as the UK and France, this focussed on colonies or ex-colonies. In terms of the three discourses identified this was the least common, however, it represents an important historical legacy reproduced in the examples that follow. Certainly in the oldest university our interviews indicated that there has been considerable activity in this area in specific departments, such as economic development, public policy and education. Some of this was continued in courses for government officials in public administration. However, partly because of an extended period in 
Africa in particular, where governments have not been able to afford fees to pay for students to study abroad, proportionally the overall provision of this sort of activity, which might have been described as aid or having an aid or developmental mission, has diminished.

Nevertheless, there are activities which fit into the contemporary picture of a globalised political economy where Western interests which can be seen as imperial continue. In one university, senior university managers from post-Saddam Hussein Iraq were receiving short courses in academic management and the message from the higher education minister was that as they had received help, scholarships would be established to enable Iraqi students to come to the institution and the British academic manager believed that 'as the security situation improves, there will be Iraqi students coming here'.

There are other ways in which the provision for international students can be seen as part of the global neo-liberal project. In one university with a programme for audit management, there was significant take up of postgraduate courses from African students paid for by their governments. The driver for this was the insistence by the World Bank that recipient countries should not only have rigorous audit programmes in place, but local administrators should be seen to be training auditors. Here, then, is an example of how money received in developing countries from the World Bank finds its way back into the UK economy - in this case as university fees.

\section{Conclusion}


There is clearly a range of reasons for the recruitment of international students in an era of globalisation. It is possible to identify the dominant rationales we have encountered from the perspective of the university. Different rationales can be seen to relate to different sectors of the university system, for example the perspective from research intensive universities is different from that of post-1992 universities, predominantly teaching orientated institutions. There is also the perspective from the point of view of the particular university's senior management which may have coherent policies and practices. But this is not necessarily the same as the perspective from the position of a school, faculty or department. The international offices, although representatives of the university, focus on marketing and recruitment without necessarily having a view which takes into account the effect of the large scale presence of international students on a particular programme.

When we analyse the complexities present within English universities who recruit international students we engaged with statements and rationales which connect, complement, qualify and sometimes contradict each other. Statements from our respondents encompass the views that a substantial contribution to academic excellence and to revenues was expected from international students. Moreover, the argument about the role of international students often moved from them as indicators of international status and excellence, to them as contributors to diversity on courses and campuses. This is seen as positive in its own right, but also improved the educational experience of both home and international students and the economic value of their qualification. 
Overall, while the generation of revenue may not have been presented first as the main driver, it was recognised everywhere as being of major importance. However, in many areas it was seen not only as simple addition to revenue, but also as a means of crosssubsidising undergraduate home and EU students. As one academic put it 'on overseas students we make a profit, on undergraduate home and EU students we make a loss'. One of the advantages of the recruitment of international students from a revenue point of view is that both recruitment levels and fees are not controlled by government funded bodies and the additional revenue is at the margin.

When we compare the rhetoric, rationales and reasons for the recruitment of international students we can detect a different emphasis between the Big Civic and County university discourse and that of the ex-CAT and post-1992 university. All of them acknowledge the importance of the revenue generated from international students, but this is articulated and connected to the significance of the presence of international students in different ways. For the Big Civic and County, and to some extent the ex-CAT, the presence of international students was taken as an indicator of international status in itself. Further, the contribution that international research students made to the research output was in itself a mark of status while the earnings accrued were only secondarily recognised. By contrast, this was seen as less important in the post-1992 university where the revenue and contribution through diversity in both cultural and curricular terms were emphasised. We can identify two aspects of the policies of universities in recruiting in the globalised higher education economy. One is the contribution to the knowledge economy which fits 
with national policy in terms of improving economic competition. This also fits with the research agenda dominant in many universities apparent in our Big Civic and County universities and to a lesser extent in the ex-CAT. Secondly in universities primarily teaching focus, the impetus to recruit international students in competition with other universities, is to fill courses and generate income. Overall the notion of international students contributing to a 'Republic of Letters or Science' in a non-utilitarian knowledge based way, was not strongly emphasised, nor was the education and training of students as an aid or development project.

We learn from the analysis of our interviews that the dominant discourse was economic and market orientated not just in terms of financial revenue, but in terms of recruitment in different markets, with more or less prestigious brands. It may be that in practice many international students do receive life changing educational experiences. This may enhance their capacity to earn, increase their status and enable them to contribute to the effectiveness, profitability and welfare of their corporations, families or countries. However, the dominant rationale for university managers' international student recruitment strategies remains the economic contribution these students make to the university's budget and their significance as a mark of the institution's international status. Our examination of university discourse and rationales for the recruitment of international students illustrates the dominance of the rationale of economic competition present at the level of the university. This is also the dominant rationale at the level of the state and can be seen in terms of a response to the challenges of globalisation. The language of economic returns, competition, commodification and the market has become 
central to the discourse of university management. This in turn is located and influenced by the developing discourse of globalisation as the political, cultural and economic processes become ever more embedded. 


\section{References}

Altbach, P.G. (2004a) Globalization and the university: myths and realities in an unequal world, Tertiary Education and Management, 10, 3-25.

Altbach, P.G. (2004b) Higher Education Crosses Borders, Change, 36, 18-25.

Ball, S. (1998) Big policies/small world: an introduction to international perspective in education policy, Comparative Education, 34(2), 119-130.

Barnett, R. (1990) The idea of higher education (Buckingham, Society for Research in Higher Education/Open University Press).

Blair, T. (2006) Why we're putting up millions to attract more students from overseas, The Guardian Education, Guardian, April, 18, 2.

British Council. (2004) Vision 2020, forecasting international student mobility: a UK perspective (London, British Council).

Currie, J. \& Newson, J. (1998) Universities and globalization: Critical perspectives (Thousand Oaks, Sage Publications).

Devos, A. (2003) Academic standards, internationalisation, and the discursive 
construction of 'the International Student', Higher Education Research \& Development, 22(2), 155-166.

Fenwick, K. (1987) Making the most of overseas students, Higher Education Quarterly, 41(2): 126-137.

Goldberg, M. P. (2006) Discursive policy webs in a globalisation era: a discussion of access to professions and trades for immigrant professionals in Ontario, Canada, Globalisation, Societies and Education, 4(1), 77-102.

Guo, Y. (2005) Asia's educational edge: current achievements in Japan, Korea, Taiwan, China and India (Lanham, Lexington Books).

Habu, T. (2000) The irony of globalization: the experiences of Japanese women in British higher education, Higher Education, 39: 43-66.

Jobbins, D. (2004) British charges are highest in Commonwealth, Times Higher Education Supplement, 20 February.

Kerr, C. (2001) The uses of the university (Cambridge, Harvard University Press).

Knight, J. (2003a) Updating the definition of internationalization, International Higher Education, 33, 2-3. 
Knight, J. (2003b) Internationalization: Developing an institutional self-portrait.

Readings for EOTU project.

Available at: http://www.eotu.uiuc.edu/events/Illinoisnovfinal.pdf

Knight, J. \& De Wit, H. (1995) Strategies for internationalisation of higher education: historical and conceptual perspectives in De Wit, H. (Ed.) Strategies for internationalisation: A comparative study of Australia, Canada, Europe and the United States of America (Amsterdam: European Association of International Education).

Knight, J. \& De Wit, H. (Eds) (1997) Internationalisation of higher education in Asia Pacific countries (Amsterdam: European Association of International Education).

Knight, J. \& De Wit, H. (Eds) (1997) Quality and Internationalisation in higher education (Paris, Organisation for Economic Co-Operation and Development).

Koutsantori, D. (2006) 'What is internationalisation?' in The leadership and development challenges of globalisation and internationalisation (London, Leadership Foundation in Higher Education).

Larsen, K. Morris, R. \& Marten, J. (2001) Trade in education services: trends and emerging issues, (Working Paper OECD).

Leadership Foundation in Higher Education (2006) The leadership and development 
challenges of globalisation and internationalisation (London, Leadership Foundation in Higher Education).

MacLeod, D. (2004) UK slips in growing overseas student market, Education Guardian, 14 September.

MacLeod, D. (2006a) Overseas student numbers rise, Education Guardian, 13 March.

MacLeod, D. (2006b) International rescue, Education Guardian, 18 April.

Marginson, S. (2002) Nation-building universities in a global environment: The case of Australia, Higher Education, 43, 409-428.

Marginson, S. (2006) 'National and global competition in higher education' in Lauder, H., Brown, P., Dillabough, J. \& Halsey, A.H. Education, globalisation and social change, (Oxford, Oxford University Press).

Miller, H. (2006) Book review of 'Asia's educational edge: current achievements in Japan, Korea, Taiwan, China and India', Globalistaion, Societies and Education, 4(1), $157-159$.

Naidoo, R. and Jamieson, I. (2005) Empowering participants or corroding learning? Towards a research agenda on the impact of student consumerism in higher education, 
Journal of Educational Policy, 20(3), 276-81.

Overseas Student Trust (1987) The next steps: overseas student policy (London, OST).

Rizvi, F. \& Lingard, B. (2006) 'Globalization and the changing nature of the OECD’s educational work' in Lauder, H., Brown, P., Dillabough, J. \& Halsey, A.H. Education, globalisation and social change, (Oxford, Oxford University Press).

Robertson, S.L., Bonal, X. \& Dale, R. (2002) GATS and the education service industry: The politics of scale and global reterritorialization, Comparative Education Review, 46, 4, 472-496.

Room, G. (2000) Globalisation, social policy and international setting: the case of higher education credentials, International Journal of Social Welfare, 9(2), 103-119.

Scherrer, C. (2005) GATS: long-term strategy for the commodification of education, Review of International Political Economy, 12(3), 484-510.

Scott, P. (1998) The globalization of higher education (Buckingham, Open University Press).

Scott, P. (2000) Globalisation and higher education: challenges for the $21^{\text {st }}$ century, Journal of Studies in International Education, 4(1), 3-10. 
Silver, H. \& Silver, P (1997) Students: changing roles, changing lives (Buckingham, Open University Press).

Tysome, T. (2004a) Overseas target is hit, Times Higher Education Supplement, 30 January.

Tysome, T. (2004b) UK market worth £10 Billion, Times Higher Education Supplement, 23 April.

Walker, M. \& Nixon, J. (2004) Reclaiming universities from a runaway world (Maidenhead, Open University Press).

Williams, L. (1987) Overseas students in the United Kingdom: some recent developments, Higher Education Quarterly, 41(2)107-118.

Yang, R. (2002) University internationalisation: its meanings, rationales and implications, Intercultural Education, 13(1) 81-95. 